\title{
SHARIA BANKING FINANCING MODEL IN ENHANCING THE HALAL CERTIFICATION OF MICRO, SMALL, MEDIUM ENTERPRISE INDUSTRY
}

\author{
Nasrulloh Nasrulloh \\ Universitas Trunojoyo Madura, Indonesia
}

$\triangle$ Corresponding Author:

Nama Penulis: Nasrulloh Nasrulloh

E-mail: nasrulloh@trunojoyo.ac.id

\section{Abstract}

A large number of Micro, Small, Medium Enterprise (MSMEs) that did not have a halal certificate yet due to lack of funds is one of the main problems in the failure of the implementation of the JPH Law mission. Halal Product Certification Agency (BPJPH) demands all products sold in Indonesia ought to have a halal certificate in 2019. This study aims to provide a model solution from the financial institution side. Islamic banking as a sharia financial institution has a strategic part to help MSMEs, offer a variety of contracts, and make MSMEs able to carry out halal certification processes. By using descriptive-analytic method, the results of this study offer the financing model with murābahah and mudhärabah contract. The financing model with a murābahah contract is applied as in the common purchasing contract. While the financing model with a mudharabah should be adjusted to the principle of profit-loss sharing with some period adjustment. The implication of this research shows that Islamic Banking can be an intermediary between the community and BPJPH. The submission process of halal certificates through the Islamic banks cooperation is considered easier, more efficient, and transparent.

Keywords: Financing Model; Islamic Banking; MSME; Halal Certification

\section{Abstrak}

Salah satu masalah utama dalam kegagalan pelaksanaan misi UU JPH adalah banyaknya UMKM yang belum memiliki sertifikat halal karena kekurangan dana dalam proses pengajuan sertifikasi halal. Undang-Undang Jaminan Produk Halal melalui Badan Penyelenggara Jaminan Produk Halal (BPJPH) menuntut semua produk yang dijual di Indonesia harus memiliki sertifikat halal pada tahun 2019. Penelitian ini bertujuan memberikan solusi model dari sisi lembaga keuangan. Perbankan syariah sebagai lembaga keuangan syariah memiliki posisi strategis dalam membantu UMKM dalam melakukan proses pengajuan sertifikasi halal melalui berbagai kontrak pembiayaan. Dengan menggunakan metode deskriptif analisis, hasil analisis dari penelitian ini menawarkan model pembiayaan dengan kontrak murabahah dan mudharabah. Model pembiayaan dengan kontrak murabahah diterapkan seperti dalam kontrak jual beli pada umumnya. Sedangkan model pembiayaan mudharabah harus disesuaikan dengan prinsip bagi hasil dengan beberapa penyesuaian waktu pembayaran. Implikasi dari penelitian ini menunjukan bahwa Perbankan syariah bisa menjadi intermediasi antara masyarakat dan BPJPH. Proses pembayaran 
pengajuan sertifikat halal melalui kerja sama dengan bank syariah dianggap lebih mudah, efisien, dan transparan.

Kata Kunci: Model Pembiayaan; Perbankan Syariah; UMKM; Sertifikasi Halal

\section{INTRODUCTION}

The government's efforts to protect the people in economic activities such as production and consumption should be appreciated. As with the issuance of Law Number 7 of 1996 concerning Products, Law Number 8 of 1999 concerning Consumer Protection, and Government Regulation Number 69 of 1999 concerning food labels and advertisements reinforces the argument that the responsibility for halal products of food, beverages, medicines, cosmetics and other products is not solely the responsibility of individuals and religious leaders, but also the responsibility of only the government.

It is a necessity and fundamental that food consumed by Muslims as large consumers of a product must obtain its halal status. In Sharia, consuming halal products for Muslims is an obligation (Tambunan, 2012), and for the sake of quality of life and life, it is the right of citizens guaranteed by the 1945 Constitution, especially the Consumer Protection Law Number 8 of 1999. Therefore, in this case, the government again issued Law no. 33 of 2014 concerning the Guarantee of Halal Products. The Urgency of Law Number 33/2014 about Halal Products Assurance (known as UU JPH) enforces all companies and household industries in the food and beverage sector to have the halal certification for their products by 2019. This policy gains various responses from the public, especially actors of economic activities such as Multi-National Companies, Banking, Tourism, Businessmen and Micro, Small, and Medium Enterprises (MSMEs).

It is a reality that MSMEs are the most strategic national economic sector and involve the lives of many people so that it becomes the backbone of the national economy. MSMEs are also the largest group of economic actors in Indonesia and have proven to be the key to safeguarding the national economy in economic crisis as well as a leading proponent of postcrisis economic growth. So in response to the Law on Halal Product Assurance, MSMEs seek to take action to be able to adjust to these regulations.

MSMEs plays a vital role in the development and economic growth, not only in developing countries but also in developed countries (Tambunan, 2012). It is widely recognized that MSMEs are very important because their main characteristics are different from the large businesses, especially because MSMEs are labour-intensive businesses, found in all locations especially in rural areas, more dependent on local raw materials, and major 
providers for goods and services for the basic needs of low-income or poor people.

Table 1. The Region Spread of MSME's Amount in Indonesia

\begin{tabular}{clcc}
\hline No. & Spread of Region & Amount of MSME & Percentage \\
\hline 1. & Jawa & 15.931 .889 & $60.66 \%$ \\
2. & Sumatera & 4.897 .457 & $18.65 \%$ \\
3. & Sulawesi & 2.134 .579 & $8.13 \%$ \\
4. & Bali \& Nusa & 1.352 .354 & $5.15 \%$ \\
& Tenggara & & \\
5. & Kalimantan & 1.352 .354 & $5.15 \%$ \\
6. & Maluku \& Papua & 451.874 & $1.72 \%$ \\
\hline
\end{tabular}

Source: BPS 2016

Table 1. source BPS data in 2016 shows that the spread of the MSME Industry in Indonesia is still centred on Java by $60.66 \%$ or around $15,931,889$ followed by Sumatra, Sulawesi, Bali \& Nusa Tenggara, Kalimantan, and Papua \& Maluku. Deputy Director of the Indonesian Food and Drug and Cosmetics Assessment Council of the Indonesian Ulama Council (LPPOM-MUI), Sumunar Jati, said that the number of halal certifications in 2016 was 1,335 companies, 1,789 certificates, and 65,599 products (Wahyudin, 2017).

The benefit of halal certification for consumers is to provide peace of consumption because the products consumed are guaranteed and safe. This is certainly the goal of all consumers. Moreover, Muslim consumers are ordered by Allah to consume halālan thoyyiban (UU No 08,1999) products as part of maqaasid al-sharia.

As an estimate, by SK.02/Dir.LPPOMMUI/I/13, the cost of halal certificates from the Riau Islands as quoted from halalmuikepri.com is differentiated into several levels: 1) Level A for the large industries with certificate fees of IDR 2 million to IDR 3.5 million. This level is for large industries or companies that have above 20 employees. 2) Level B is for the group of a small industry that has between 10-20 employees. The certificate costs IDR 1.5 million to IDR 2 million. 3) Level $\mathrm{C}$ is for a home-based business that has less than 10 employees. This level needs to spend IDR 1 million to get an MUI halal certificate. All the nominal above does not include other costs, such: auditor, registration, journal magazines, training, additional costs (IDR 200.000 if the company has outlets), training cost (IDR $1.200 .000 /$ person for the company and IDR 500.000/person for MSE), and the charge for additional product (IDR 150.000/product for Level A, IDR $100.000 /$ product for Level B, and IDR 50.000/product for Level C). (Puri, 2020)

For producers, the halal certification has implications for winning the global market because the product has a unique selling point as a way to 
compete with competitors. Halal-certified products are certainly safe and secure products to gain consumer confidence, especially since Indonesia is one of the countries with the largest Muslim consumers in the world.

To gain the business capital, the MSME Industry requires fresh funding from the Islamic banking industry to develop its business in the form of mudhārabah or musyārakah financing. The two contracts are excellent in the Islamic banking industry today. On the other hand, both mudhārabah and musyārakah have fair, transparent, and negotiable margin portions. There may have any other contracts that can be able to contribute to the progress of the MSME Industry and help to push the government's target for the Halal Product Assurance Law through the salam, istishna', ijarah, and many more. This thing needs to be done and explored further because, in line with the mission of the Islamic banking industry in Indonesia, it has passed more than a quarter of a century, but its movements are considered to have no significant effect. There is still a lot of homework that should be able to be done in the short and long term. So we need concrete steps and appropriate breakthroughs in utilizing the existing opportunities.

This paper seeks to offer a concept to the synergy between BPJPH as an institution that issues halal certificates, the Islamic banking industry as a financial provider and MSMEs as the beneficiaries of financing and halal certificates for their products in the success of the government's mission has been stated in Law No. 33/2014 on Halal Product Assurance.

\section{LITERATURE REVIEW}

\section{Shariah Banking and MSME's Financing}

The definition of a Sharia Bank or Islāmic Bank is a bank that operates by Islāmic sharia principles or banks that run by Islāmic sharia regulations. In the muamalah procedure, uses the investment activities based on profit sharing and trade finance and avoids the contract that contains elements of usury (Perwataatmadja, 1992).

The Islāmic banks ought to carry out their activities based on Islāmic legal principles. The Islāmic banking industry must apply proper principles and should be in line with the Islāmic law rules. Here are some basic principles of Islāmic bank products which are divided into five (5) principles, there are: 1) Deposit; Al Wadi'ah/Depository, 2) Principles for Profit Sharing; Mudhārabah (Trust Financing) and Musyārakah (Partnership) 3) Principles of Sale and Purchase; Murābahah (cost-plus financing), Salam (In-front of Payment Sale) and Isthisna' (Purchase by Order or Manufacture) 4) Lease Principle; Ijārah (Operational Lease) and the last 5) Fee-based Service ; Wakalah (Deputy Ship), Kafalah (Guaranty), Hawalah (Transfer od Debt), Ar Rahn and Al Qardh. 
According to RI Law number 20/2008 on Micro, Small and Medium Enterprises Chapter 1 Article 1:

Microbusiness is a productive business owned by the personal owner and or personal business entities that meet the criteria for micro business. A small business is a productive business that is carried out by the personal owner or business entities that are not a subsidiary of a company that is owned, controlled, or is a part either directly or indirectly of medium or large businesses that meet the criteria of small businesses. A medium-scale business is a productive economic business that is carried out by a personal owner or business entity that is not a subsidiary or branch of a company that is owned, controlled, or becomes a part either directly or indirectly with a small business or large business with a net worth or annual sales results.

In this Law it is regulated that the empowerment of Micro, Small and Medium Enterprises needs to be carried out thoroughly, optimally and continuously through the development of a conducive climate, providing business opportunities, support, protection, and the broadest possible development, to increase the position, role and the potential of Micro, Small and Medium Enterprises in realizing economic growth, equity and increasing people's income, job creation, and poverty alleviation (Ridwan, 2014).

To distinguish MSMEs, Law No. 20/2008 Article 6 on MSMEs classifies MSMEs to the following criteria:

a) Criteria for microenterprise according to Law No. 20/2008 Article 6 on MSMEs Chapter IV Article 6: Has a net worth at most IDR 50,000,000 (fifty million rupiahss) excluding land and buildings for business premises; or have annual sales results at most IDR 300,000,000 (three hundred million rupiahss).

b) Criteria for small businesses According to Law No. 20/2008 Article 6 on MSMEs Chapter IV Article 6: Has a net worth more than IDR $50,000,000$ (fifty million rupiahs) to IDR 300,000,000 (three hundred million rupiahs) excluding land and business premises; or have annual sales results more than IDR 300,000,000 (three hundred million rupiahs) and at most IDR 2,500,000,000 (two billion five hundred million rupiahs).

c) Criteria for medium-sized businesses According to Law No. 20/2008 Article 6 on MSMEs Chapter IV Article 6: Has a net worth more than IDR 500,000,000 (five hundred million rupiahs) to IDR 10,000,000,000 (ten billion rupiahs) excluding land and buildings for businesses; or have annual sales results more than IDR 2,500,000,000 (two billion five hundred million rupiahs) to IDR $50,000,000,000$ (fifty billion rupiahs) 


\section{The Urge for Halal Certification for the MSME's Product}

Every food and beverage company or business will not be separated from halal certificates to offer the certainty of the halal status of their product and it should provide inner peace for their consumers. Because of this urge influential for the consumers and markets, the business management has to afford requirements as enforced by the government regulations (Baihaki, 2014).

According to the Indonesian Ulama Council (MUI), the Halal Certificate is a written fatwa from MUI which states the halal status of a product by Islāmic shariah and this certificate is issued by BPJBH. This Halal Certificate is a prerequisite for obtaining halal labelling let on the product packaging from an authorized government agency. Halal certification is security assurance for Muslims to consume a food product according to Islāmic teachings. Halal certification also signifies the quality, cleanliness, and hygiene of a product. Halal-certified products can be proven with the halal logo on the product packaging. This product has been proven to pass the halal test by MUI. Products that are proven Halal have gone through a series of processes and tests that are proven to not contain impurity and are allowed to be consumed (Waskito, 2016).

Contracts Construction in Sharia Banking Product Development in Indonesia by Ghofur explained that the purpose of the research was to present strategic steps in the development of Islāmic banking products while still being bound by the principles and values of sharia. These steps are: 1) reconciliation about the understanding of contracts in Islāmic banks; 2) optimizing the role of the Sharia Supervisory Board (DPS); 3) empowering the socio-economic potential of the community. Islāmic banking is believed to be able to meet the demands of the community in realizing social welfare with those three steps (Ghofur, 2015)

Qomaro, in Consumer Perceptions of Halal Certification in Food Products in Bangkalan, resulted in the low level of consumer understanding of halal certification; consumer perceptions of halal certification in food products in Bangkalan are also low, and analysis of the relationship between consumers' demographic profiles and halal certification has good potential, but there is a need for support and socialization from local and central government (Qomaro, 2018)

On the topic of sharia banking studies, the halal industry and MSMEs, previous researchers identified more about the potential of MSMEs, the construction of banking contracts and the effect of halal labelling on society. Not many studies have examined the concept of Islāmic banking in helping the halal certification registration process through the construction of financing contracts. The novelty of this research is trying to find the role of 
Islāmic banking in helping to realize MSMEs halal certification products in Bangkalan through the halal certification financing model according to the mandate of Law No.33/2014 on Halal Product Guarantee.

\section{METHODS}

This is a qualitative descriptive study with a literature study approach and in-depth interviews. This is descriptive qualitative research. The data are obtained from observations and literature studies as primary data as well as secondary data and other supporting documentation data. Research data generated through observation and interviews. This paper uses the structured interview as the researcher has known the purpose of the information. The author had interviewed the main informant, they are: 1) Ali Afandi as the Chief of Bangkalan Cooperation Department; 2) Ahmad Muhlas as The Secretary of Bangkalan Cooperation Department; 3) Titien Ardia as the Head Section of Bangkalan Cooperation Department. 4) Achmad Rifan as the senior marketing of Bank Mandiri Sharia, and 5) Ahmadi as the deputy of Halal Product Guarantee Agency (BPJPH). To show the data analysis uses a descriptive method, which describes the MSMEs and the Islamic banking financing models and illustrates the results of observations and interviews that have been obtained in Bangkalan. Furthermore, new concepts of the financing model will be developed by continuing existing concepts, then from this analysis, conclusions and suggestions can be drawn.

\section{RESULTS AND DISCUSSION}

\section{Micro Small Medium Entrepreneurs Industry in Bangkalan}

The official website of the Cooperative and MSMEs Office in Bangkalan has released that over the last three years the government has carried out various activities to empower Micro Enterprises. These activities are the government's efforts to improve the soft skills of the target communities and increase the level of profitability of their businesses. The Chief of Bangkalan Cooperation Department stated that of the 100 MSMEs that are officially registered as assisted by the Bangkalan government, only 6 are willing to process halal certificates for their products while the rest are still not aware of the submission process.

Figure 1. shows that the MSMEs industry in Bangkalan Regency is dominated by the culinary sector, education, fashion \& cosmetics, and plants, medicine \& herbs. Of the 10 UMKM sectors, only 6\% willing to carry out the halal certification process while others do not yet know. This is following what was conveyed by Mr. Afandi as the Head Coordinator of the Kab. Bangkalan. 
"In Bangkalan, there are more than 100 assisted by Micro Enterprises. We already know about halal certification, but the realization is very difficult. We have only been assisted by 6 Districts who want to process it, but to date, there has been no result. While the most are not yet aware of it" (A. Alfian, personal communication, 2019).

Table 2. The Agenda to Empower SMEs in Bangkalan

\begin{tabular}{cll}
\hline No. & \multicolumn{1}{c}{ Activity Type } & Year \\
\hline 1. & $\begin{array}{l}\text { Encourage Economic Independence of Blacksmiths } \\
\text { 2. }\end{array}$ & $\begin{array}{l}\text { Establishment and Development of the MSMEs Clinic } \\
\text { Cooperative Office }\end{array}$ \\
3. & $\begin{array}{l}\text { Socialization in Facilitating the Improvement of Micro, } \\
\text { Small, and Medium Business Partnerships }\end{array}$ & 2017 \\
4. & $\begin{array}{l}\text { SME Infrastructure Network Development Activities in } \\
\text { Bangkalan Regency Cooperatives and Micro Business }\end{array}$ & 2017 \\
& $\begin{array}{l}\text { Offices } \\
\text { Facilitation of Development of Production Promotion }\end{array}$ & 2017 \\
& $\begin{array}{l}\text { Facilities of Bangkalan Cooperative and Micro } \\
\text { Business Services }\end{array}$ & \\
\hline Source: Department of Cooperatives and SMEs Kab. Bangkalan 2019
\end{tabular}

Of the 18 Sub-districts in Bangkalan, only 6 sub-districts have been recorded. That is due to the lack of government attention to the regional budget. Another fact was conveyed that public awareness is still difficult and the absence of official authority to help cut the bureaucratic chain of halal certification.

"How can they are aware of halal certificates when it is still difficult to register business licenses. Moreover, the department does not have authority on this matter. So they usually go to the health department to be administered directly to be tested by the laboratory and BPOM first, not to halal certification. The ration is about 10 products/ month" (T. Ardia, personal communication, January 2020)

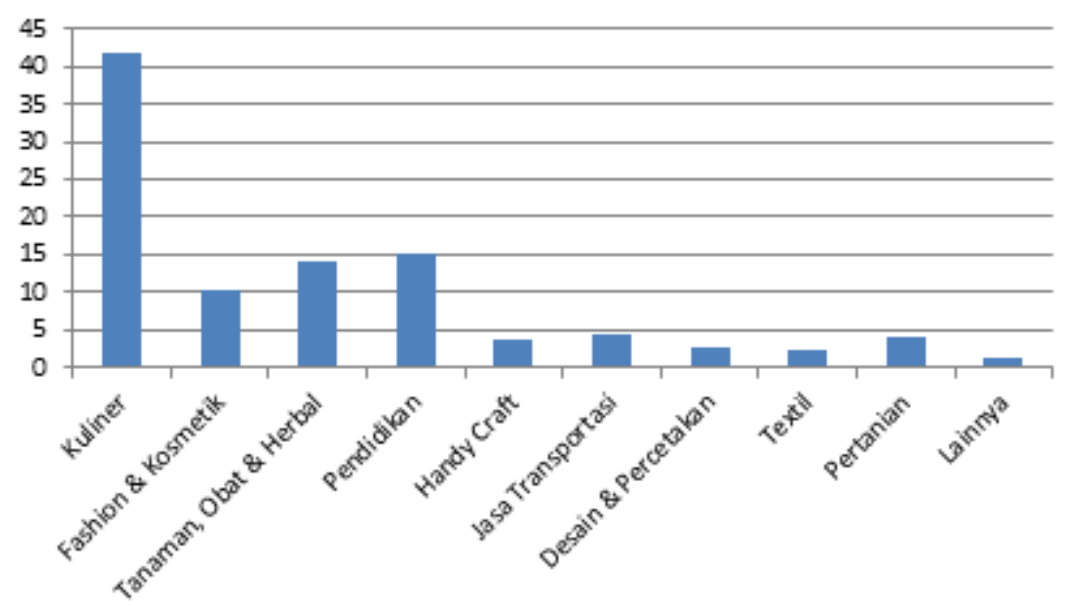

Figure 1. The Distribution of Bangkalan MSMEs Based on Clusters Source: DISKOPUMKM Kab. Bangkalan, Data processed by Researchers, 2019 


\section{Cooperation of BPJPH and Banking Industry in Registration of Halal Certification for MSMEs}

The local community has experienced several obstacles in carrying out the process of ownership of halal certificates on the business products: the difficult bureaucratic problems, expensive cost of the certification process, and public awareness (awareness) of the importance of halal certification registration. This fact is certainly worrying so that there needs to be an efficient shortcut in overcoming it (T. Ardia, responden, January 2020).

To help the process of halal certification registration for MSME actors, there needs to be cooperation between various parties, including the banking sector as an important element in financing MSMEs and BPJPH as the issuer of halal certificates for MSMEs. A proper financing model is needed so that co-operation between BPJPH and Islāmic Banking can be a help for MSMEs

Ahmadi, on Exposure from Representatives of the Halal Product Guarantee Agency for Halal Certification at the 2nd Annual Conference on Islamic Economic \& Law, stated:

"Conducting collaborative actions with the banking industry is a brave step, I appreciate it. But so far BPJPH has not cooperated with the banking industry in terms of issuing halal certificates, because issuing halal certificates is an absolute duty of BPJPH. Then if it is recommended, it may be permissible if banks make products whose main task is to conduct halal certification financing activities. So the collaboration here is not to allow banks to issue, but to make products for halal certification." (Penyelenggara Jaminan Produk Halal Terhadap Sertifikasi Halal, 2019)

But in fact, Islāmic banking as part of government stakeholders in the realization of government programs has not been fully able to respond to community needs. Unlike the management assistance and submission of bailout funds to the Hajj program which has been implemented for a long time, the halal certification program that is in line with the Ministry of Religion cannot be accommodated by Islāmic banking because there is no exact formula in the implementation of the financing model.

"It's a bit difficult to publish because we are not the agency appointed for it. It's different when it comes to hajj funds that we can handle. The object is the money since the halal certification is an ordinary object. The feedback for us on this project is not clear. Unless there are alternatives, for example using product development, it might work. But it needs to be reviewed and considered carefully." (A. Rifan, responden, December 2019)

Based on the responses of each resource person, each institution has its territorial power, so it cannot carry out institutional processes outside the 
established rules. It can be concluded that there is still a gap to be able to realize the demand and supply of the problem so that it can be an option in solving the problem of applying halal certification for MSMEs in Bangkalan.

The author offered two financing models as alternatives to the government or financial institutions to increase public awareness of halal certification. The synergy between financial institutions or Islāmic banking with the government or Halal Product Certification Agency (BPJPH) is important for the success of this program

\section{Halal Certification Financing Model with the Principle of Buying and Selling (Murābahah)}

The purpose and goals of the halal certification financing model by using the murābahah contract is the Islāmic banks' issue financing products that focus on financing halal certification. In general, the object of the financing contract is in the form of electronic goods, motor vehicles, or other valuables things, but the object of the financing contract is a halal certificate. For more details, consider the Figure 2 with notes:

Notes:

1. The customer applies to the procurement of halal certification, and the bank makes observations about the customer's eligibility

2. If the customer's request is accepted, the bank will conduct a financing transaction using a muräbahah contract with the customer. The customer pays down payment (DP), the rest will be paid by instalments for a period determined by the bank and agreed by both parties

3. The Bank carries out an act of purchasing or processing halal certification to the institution (BPJBH) in the same period and submitted directly to the customer or can be taken by the customer if the process has been completed.

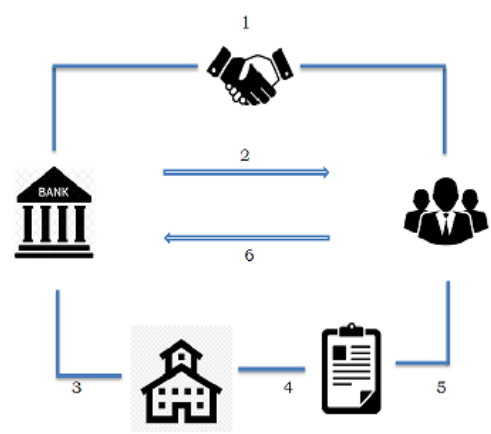

Figure 2. The flowchart of Halal Certificate Financing with Murābahah Contract at Islāmic Banks

Source: (A. Rifan, personal communication, 2020) 
4. After the halal certificate is completed, the customer is obliged to pay instalments to the bank

5. The bank benefits from a predetermined margin between the price set by BPJPH and the customer's agreement through the bank.

\section{Halal Certification Financing Model with the Partnership Method (Mudhārabah)}

The purpose and goal of the halal certification financing model by mudharabah contract is the Islāmic bank issues a financing product that focuses on equity participation to customers with a percentage of profit margin at the end of the period to pay off the process of issuing the halal certification. Thus, the customers get working capital and halal certificates from this financing model (Figure 3) with notes:

1. The customer applies to the procurement of other capital through a mudhārabah contract with the end of the percentage ratio of the profit-sharing percentage to finance the halal certificate, and the bank observes the customer's feasibility

2. If the customer's request is accepted, the bank will conduct a financing transaction in working capital using a mudhārabah contract with the customer. The customer and the bank agree at the beginning of the contract by explaining the percentage ratio. The profit-sharing ratio can be $40 \%$ for banks and $60 \%$ for customers.

3. The customer conducts or continues his business within a certain period. When it is profit, the profit-sharing ratio will be divided according to the part. 5-10\% of the customers' profit percentage will be used to pay the bank because they have taken care of halal certificates. So that, at the end of the period, a customer obtains the profit of around 50-55\%

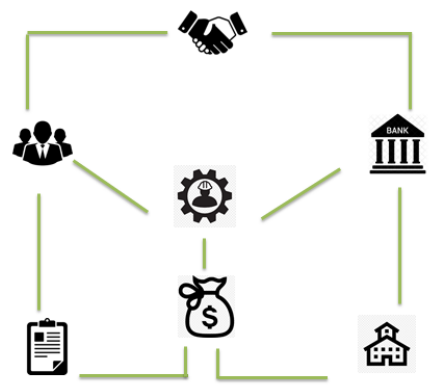

Figure 3. The flowchart of Halal Certificate Financing with mudhärabah contract at Islāmic Banks.

Source: (A. Rifan, personal communication, 2020) 
4. The Bank carries out an act of processing halal certification to the institution (BPJPH) in the same period and handed over directly to the customer or can be taken by the customer if the process has been completed.

5. After the halal certificate is completed, the customer is obliged to pay instalments to the bank through the percentage of profitsharing ratio as at the beginning of the contract.

6. The bank gets the benefits from the profit-sharing ratio, the determined margin, and the certificate cost from BPJPH with the customer's contract through the bank.

7. The halal certificates can be taken directly by the customer to BPJPH or at the bank, with terms and conditions agreed as at the beginning of the contract.

Based on the results of the research, it is stated that the two models are alternative options that can be taken into consideration for the banking industry in particular and MSMEs industry players in financing the registration process for halal certification for MSMEs products and helping the Government to accelerate the equal distribution of halal certification for all MSMEs products. The contracts models mentioned above are only focused on murābahah and mudhärabah contracts but it is the possibility to use other Islamic contracts. It is necessary to develop a financing model from Islāmic Banking as well as cooperate with other stakeholders in various forms to accelerate the realization of the government's mission.

\section{CONCLUSION}

Sharia banking as a funds provider can bring up certain financing models that can help MSMEs players to help in the halal certification registration process. Islāmic Banking can work with BPJPH as the authorized party to issue halal certificates to handle the registration process. This should be very possible considering Islāmic Banking has cooperated with the Ministry of Religion in Hajj Registration.

The MSMEs can apply the financing model with murābahah and mudharabah contract to have cooperated with the Islāmic Banking. The financing model with the murābahah contract is simpler so that it is easily applied to both business people or customers and Islāmic banking. The financing model with mudharabah contract is more complex because it must adjust to the principle of profit-sharing and a long period. Both of these financing models have advantages and disadvantages each, but the essence of 
getting halal certificates through Islāmic banks is easier, more efficient, and transparent.

\section{REFERENCES}

AAOIFI. (2004). Accounting and Auditing Organization for Islamic Finance Institution; Standar Mengenai Syirkah (Musyārakah), klausul 2/1

Al Husaini, Imam Taqiyuddin Abu Bakar, Kifayat Al-Akhyar. Semarang: Toha Putra, tt.

Al Jaziri, Al Fiqh 'ala Al-Madzāhib Al Arba'ah. (2003). Beirut-Lebanon : Daarul Kutub Al 'Ilmiyah.

Antonio, M. Syafi'i. (2009). Bank Syariah: Dari Teori ke Praktek, cet. ke-14. Jakarta: Gema Insani.

Ayub, Muhammad. (2009). Understanding Islamic Finance. Jakarta: Kompas Gramedia, Alih Bahasa; Aditya Wisnu.

Baihaki, Muhammad. (2014). Pengaruh Tidak Adanya Sertifikat Halal Terhadap Keputusan Pembelian Produk Ayam Goreng Tepung Menurut Perspektif Ekonomi Islam (Studi Kasus di Desa Tanjungsamak, Kec. Rangsang, Kab. Kepulauan Meranti) Skripsi, Universitas Islam Negeri Sultan Syarif Kasim, Riau .

Hendi, Suhendi. (2002). Fiqh Muamalah. Jakarta: PT. Raja Grafindo.

Qomaro, Galuh Widitya. (2018). Persepsi Konsumen Terhadap Sertifikasi Halal Pada Produk Pangan Di Kabupaten Bangkalan. Jurnal Kabilah: Journal of Social Community. 3(2).

Karim, Adiwarman. (2006). Bank Islam. Jakarta: Raja Grafindo Persada.

Munawwir, Warsun. (2013). Kamus Bahasa Arab Al Munawwir cet. ke-3, Surabaya: Pustaka Progressif.

Perwataatmadja, Karnaen dan Muhammad Syafi'i Antonio. (1992). Apa dan Bagaimana Bank Islam. Yogyakarta: Dhana Bakti Wakaf.

Rachmat, Syafe'i. (2010). Fiqih Muamalah. Jakarta: Rajawali Press.

Ridwan, Muh., dkk. (2014). Pembinaan Industri Kecil dan Menengah Pada Dinas Perindustrian, Perdagangan, Koperasi dan UMKM Kota Bontang, Jurnal Administrative Reform, 2(2).

Ruslan, Abdul Ghofur. (2015) Konstruksi Akad Dalam Pengembangan Produk Perbankan Syariah Di Indonesia. Jurnal Al 'Adalah. 12(1). Universitas Raden Intan Lampung

Sabiq, Sayyid. Fiqh As-Sunnah. (1977). Cetakan ke-3, juz 3. (Beirut: Dar AlFikr.

Sarwido dan Dwi Retno. (2014). Model Optimalisasi Daya Saing Dan Sinergivitas Kinerja UMKM Di Jepara. Jurnal DISPROTEK. 5(1).

Soemitra, Andi. (2012). Bank dan Lembaga Keuangan Syariah. Cetakan ke-3. Jakarta : Kencana Prasada Prenada Media Group.

Surat Edaran Bank Indonesia No. 10/14/DPbS tentang Pelaksanaan Prinsip Syariah dalam Kegiatan Penghimpunan Dana dan Penyaluran Dana serta Pelayanan Jasa Bank Syariah ("SEBI 10/2008")

Tambunan, Tulus. (2012). Usaha Mikro Kecil dan Menengah di Indonesia: isuisu penting. Jakarta: LP3ES. 
Tedjasuksmana, Budianto. (2014). Potret UMKM Indonesia Menghadapi Masyarakat Ekonomi ASEAN 2015. The 7th NCFB and Doctoral Colloquium 2014. ISSN NO : 1978 - 6522

Undang-Undang No. 08 Tahun 1999 Tentang Perlindungan Konsumen

Undang-Undang RI nomor 20 tahun 2008 tentang Usaha Mikro, Kecil, dan Menengah

Waskito, Danang. 2015. Pengaruh Sertifikasi Halal, Kesadaran Halal, Dan Bahan Makanan Terhadap Minat Beli Produk Makanan Halal (Studi Pada Mahasiswa Muslim Di Yogyakarta). Tesis. Universitas Negeri Yogyakarta.

Wahyudin, M Iqbal, Suryana, Neni S Wulandari. (2017). Non Performing Financing (NPF) And Bank Indonesia Sharia Certificate (SBIS) Towards Sharia Financing In The Sector Of Micro, Small, And Medium Enterprise (MSME) In Indonesia. ICIEBS. 1(1). 78-82

Widodo, Sugeng. (2014). Moda Pembiayaan Lembaga Keuangan Islam; Berdasarkan Perspektif Aplikatif, Yogyakarta: Kaukaba.

Yunus, Sabari Hadi. (2010). Metode Penelitian Wilayah Kontemporer. Yogyakarta: Pustaka Pelajar.

Zulkifli, Sunarto. (2003). Panduan Praktis Transaksi Perbankan Syariah. Jakarta: Zikrul Hakim. 